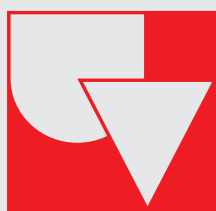

Universidad del Valle

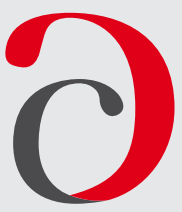

Cuadernos de Administración
Journal of Management

Print ISSN: 0120-4645 / E-ISSN: 2256-5078 / Short name: cuad.adm.

Pages: 64-77 / Vol: 36 / Issue: 66 / Jan. - Apr. 2020

Faculty of Administration Sciences / Universidad del Valle /

Cali - Colombia

\title{
Work productivity management in knowledge-intensive service companies: considerations and challenges
}

\author{
Gestión de la productividad laboral en empresas de servicio intensivas \\ en conocimiento: consideraciones y desafíos
}

\author{
${ }^{1}$ Omar Alberto Tapasco-AlzateiD \\ Assistant Professor, Department of Mathematics, School of Exact and Natural Sciences, Universidad de Caldas \\ Manizales, Colombia. e-mail: omar.tapasco@ucaldas.edu.co

\section{Jaime Alberto Giraldo-García(D)} \\ Head Professor, Industrial Engineering Program, School of Engineering and Architecture, Universidad Nacional \\ de Colombia Sede Manizales, Colombia. e-mail: jaiagiraldog@unal.edu.co
}

\section{${ }^{3}$ David Osorio-García(iD}

Associate Professor, Department of Anthropology and Sociology, School of Legal and Social Sciences, Universidad de Caldas, Manizales, Colombia. e-mail: david.osorio@ucaldas.edu.co

Article of Scientific and Technological Research
Submitted: $28 / 08 / 2019$
Reviewed: $10 / 12 / 2019$
Accepted: $10 / 02 / 2020$
Thematic lines: Administration and Organizations
JEL classification: J24, M12, L80, J29
DOI: https://doi.org/10.25100/cdea.v36i66.8465

\begin{abstract}
The purpose of this research is to inquire about the different considerations and perspectives that arise regarding the concept of productivity in the knowledge work context, as well as the main challenges that emerge in knowledge workers' productivity management. A group of managers and workers from organizations in the knowledge-intensive services sector was interviewed. We resorted to content analysis to process the information, taking borrowing elements extracted from the systematic literature review for coding purposes. The perspectives among the interviewees regarding the concept of productivity diverge, and these differences are connected to the type of company and the role of the interviewee: manager or worker. The challenges reported include time management, complexity, heterogeneity, intangibility and task multiplicity, as well as the challenge for managers to set guidelines to measure and monitor productivity without affecting worker welfare. It becomes necessary to approach the concept of productivity from a holistic perspective, and to implement alternative managerial practices that take into account the nature of the work done, worker satisfaction and the diverse perspectives of stakeholders.
\end{abstract}

Keywords: Work productivity, Personnel management, Knowledge intensive services, Workers.

1 Chemical Engineer, Doctor (c) in Engineering- Industry and Organizations, Universidad Nacional de Colombia Sede Manizales, Colombia.

2 Industrial Engineer, Doctor in Engineering, Universidad Nacional de Colombia Sede Manizales, Colombia.

3 Anthropologist, Master in Social Sciences, Universidad de Caldas, Colombia. 


\section{Resumen}

El propósito de la investigación es indagar sobre las distintas consideraciones y perspectivas que surgen con respecto al concepto de productividad en el contexto del trabajo del conocimiento, así como los principales desafíos que emergen para la gestión de la productividad del trabajador del conocimiento. Se entrevista a un grupo de directivos y trabajadores de organizaciones del sector de servicios intensivos en conocimiento. Se acude al análisis de contenido para el tratamiento de la información, tomando para su codificación, elementos conceptuales extraídos de la revisión sistemática de literatura. Se observan divergencias en las perspectivas entre los entrevistados en torno al concepto de productividad, diferencias que muestran relación con el tipo de empresa y el rol del entrevistado, directivo o trabajador. Entre los desafíos reportados se enfatiza en la gestión del tiempo, la complejidad, heterogeneidad, intangibilidad y la multiplicidad de las tareas, y el reto que representa para los directivos establecer directrices para la medición y el seguimiento de la productividad sin afectar el bienestar del trabajador. Se hace necesario asumir el concepto de productividad desde una perspectiva holística, así como implementar prácticas de gestión alternativas, que contemplen la naturaleza de la labor realizada, la satisfacción del trabajador y las diversas perspectivas de los grupos de interés.

Palabras clave: Productividad laboral, Gestión de personal, Servicios intensivos en conocimiento, Trabajadores.

\section{Introduction}

Nowadays, the business environment is strongly supported in a knowledge-based economy, turning knowledge workers into one of the main resources to preserve and promote corporate competencies (Arsalan, Dahooei, and Shojai, 2014). The number and share of workers in this sector is increasing rapidly worldwide when compared to manual labor, but little is known about the factors that foster labor productivity despite such dynamism (Adriaenssen, Johannessen, and Johannessen, 2016). Given that the success of contemporary companies lies primarily in knowledge workers, improving their productivity and performance becomes a key factor in economic growth (Ruostela and Lönnqvist, 2013).

Effective means to monitor them become necessary in order to improve their productivity. Specifically, a productivity measuring system could help monitor individual performance, identify unusual patterns and inquiry about the causes related thereto and practices, and determine which differences are attributable to the individual and which to the work system, or determine the impact of new technologies or new management philosophies. They could also help in improving staff recruitment processes by identifying redundant skills, producing productivity forecasting, strategic planning, determining comparison standards, assigning tasks, rewards and bonuses, as well as in reducing subjectivity in evaluations (Ramirez and Nembhard, 2004).

Regarding the definition of the knowledge worker, there are those who state that it is one with a high degree of expertise, education or experience, whose fundamental purpose is to create, distribute or apply knowledge (Davenport, 2008). While others resort to defining it not by title or educational level but by the nature of the work performed. In this sense, knowledge-intensive work is characterized by the following nonmutually exclusive attributes: high autonomy levels, knowledge, intangibility, creativity and innovation and complexity; and little structuring, physical effort, routine and repetition (Ramirez and Steudel, 2008).

The so-called Knowledge Intensive Service (KIS) bring together segments as diverse as accounting and legal services, architecture, audiovisuals, engineering, software, advertising, research and development (R\&D) or health and education services. Despite the obvious differences, all of them share the characteristic of intensively employing highly qualified human resources, and being both users and producers of information and knowledge to provide services to clients. A subset of these is Knowledge Intensive Business Service (KIBS) companies, i.e., those that involve economic activities whose main purpose is profit. However, it is important to note that some activities are not provided solely by specialized firms, but organizations whose core business is manufacturing or primary production generate them as well (López and Ramos, 2013).

Generally speaking, productivity is defined as the relationship between outputs generated and inputs used. In particular, work productivity is related to the variation of yields depending on the work needed to 
add value to the final product. But due to differences with traditional manufacturing, its application in the field of knowledge work is more complex. Among such differences is that high levels of complexity characterize the latter, which it reflects in high number and interrelation of sub-tasks during the provision of the service; as well as variability, to wit, the probability of changes during the provision of the service; and uncertainty that becomes evident in the limited availability of resources required, especially those of the client, as well as heterogeneity in service inputs, such as qualification and employee motivation (Ruostela and Lönnqvist, 2013). Moreover, service transformation processes often include customer engagement, with intangible results that are not easily standardized.

This paper initially addresses some considerations and divergences that emerge around the concept of work productivity in the context of knowledge work. Supported on a systematic literature review, some theoretical elements are defined and contrasted against the actual perception of managers and workers in different organizations of the KIS sector have about the concept in question. Thereafter, by turning to content analysis, we learned the main difficulties and challenges that arise in knowledge workers productivity management.

\section{Methodology}

The research carried out is two-purpose, as it seeks to answer the following questions: what is the concept of productivity in relation to the knowledge worker? And what are the administrative challenges that knowledgeintensive services companies face in managing the productivity of their workers? For this purpose, a systematic review was conducted that aimed at identifying the scientific literature written in the field, which was carried out by covering papers published in the Web of Science and Scopus databases between 2000 and 2019, and taking the keywords as the unit of analysis. We used the following search equation for such purpose, specifying that the asterisk (*) is used in order to increase the rate of results matching the words with this semantic root: "(Measurement OR measur*) AND (Productividad OR
Productivity OR Performance) AND (“Trabajo del Conocimiento" OR "Knowledge Work*" OR KIBS)".

Subsequently, we resorted to the collection of empirical information in 16 organizations of the knowledge-intensive sector in the city of Manizales, Colombia. Twenty semistructured face-to-face interviews were conducted in these organizations, fifteen of them with managers and five with knowledge workers. Abiding by the confidentiality agreements signed with the participating organizations, the data presented herein have been described in an aggregate and summarized manner. Since sampling in this research was intentional rather than random, it was important to find individuals that could generate information-rich cases, that is, those capable of providing non-redundant information on key topics for the purpose of the research (Patton, 2002).

The analytical strategy used in this research was content analysis from the perspective of Schreier (2012). The main objective of this strategy is to systematically describe the meaning of a qualitative data set, which implies three characteristics: data reduction, systematicity and flexibility (Flick, 2014, p. 170). A conceptual strategy through the construction of a matrix of codes guided the work, and such quality allowed to retain the one-dimensionality, mutual exclusivity and completeness of the codes (Flick, 2014, p. 175). In turn, a pilot test was carried out where codes and application rules were adjusted, allowing the input of new perspectives gathered from the data. The findings were then presented through semantic networks and text matrices, categorically comparing the content between the two research sources: managers and workers. All this was done with the support of the licensed software Atlas.ti, version 8. Finally, we moved on to use the Multiple Correspondence Analysis (MCA), a technique to reduce categorical interdependent data (Díaz, 2002).

Bearing in mind the aforementioned analytical approach and with a view to systematize the information provided by the interviewees, the representative codes are obtained to reflect the conceptual categories that make up productivity. To this end, the 


\begin{tabular}{|c|c|}
\hline Concept & Description \\
\hline Traditional definition & Output quantity relative to input quantity, such as the time taken to produce the output \\
\hline Quantity & Product and Results Counting \\
\hline Efficiency & It means doing things right. Tasks are done by meeting all time, quality, etc. standards \\
\hline Effectiveness & It means doing the right things. Implementation of actions aimed at achieving objectives \\
\hline Customer Satisfaction & They explain the fact that products need to add value to the customer \\
\hline Self-assessment & One's own perception of productivity \\
\hline Quality & It explains how good the work done is \\
\hline Profitability & Monetary value of production relative to labor costs \\
\hline Empowerment & It reports the worker's independence and autonomy to carry out his work \\
\hline Innovation and Creativity & Such as the amount of ideas developed to improve products, services or processes \\
\hline Absenteeism & It helps interpret the results of average productivity measurement \\
\hline Other factors & Job satisfaction, knowledge transfer, among others \\
\hline \multicolumn{2}{|r|}{ Source: Adapted from Ramirez \& Nembhard (2004) } \\
\hline
\end{tabular}

Figure 1. Knowledge Work Productivity Keywords Co-occurrences Network

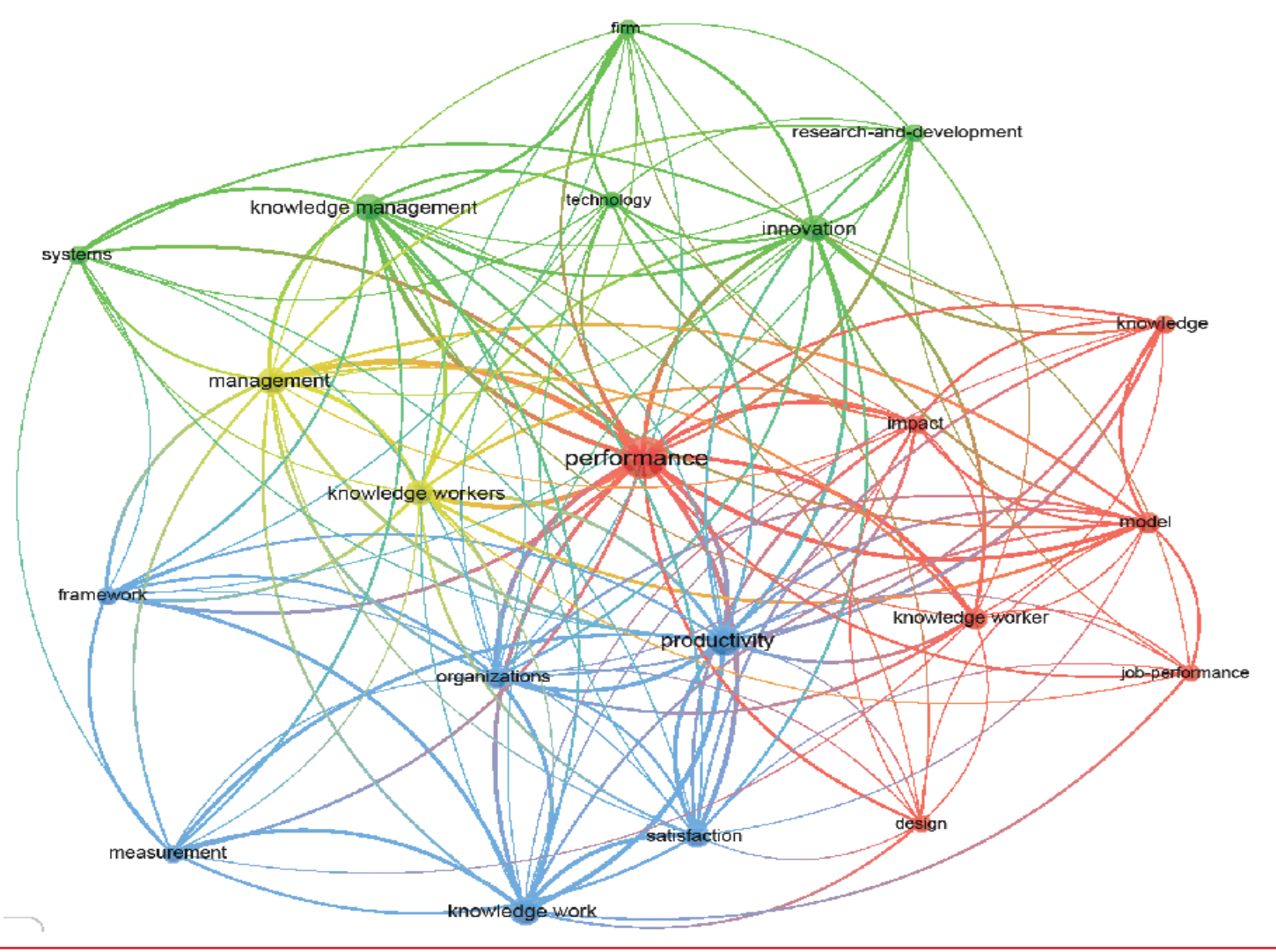

Source: Authors' own elaboration using the software VosViewer v. 1.6.11.

codification work is based on the proposal made by Ramirez and Nembhard (2004) to categorize the constituent elements of the concept of productivity in the context of knowledge work, as shown in Table 1.

\section{Results and discussion}

Given the above specifications, the search equation applied yielded 127 papers referenced in the Web of Science and 262 in Scopus. Figure 1 presents the bibliographic 
Figure 2. Word cloud on the concept of productivity

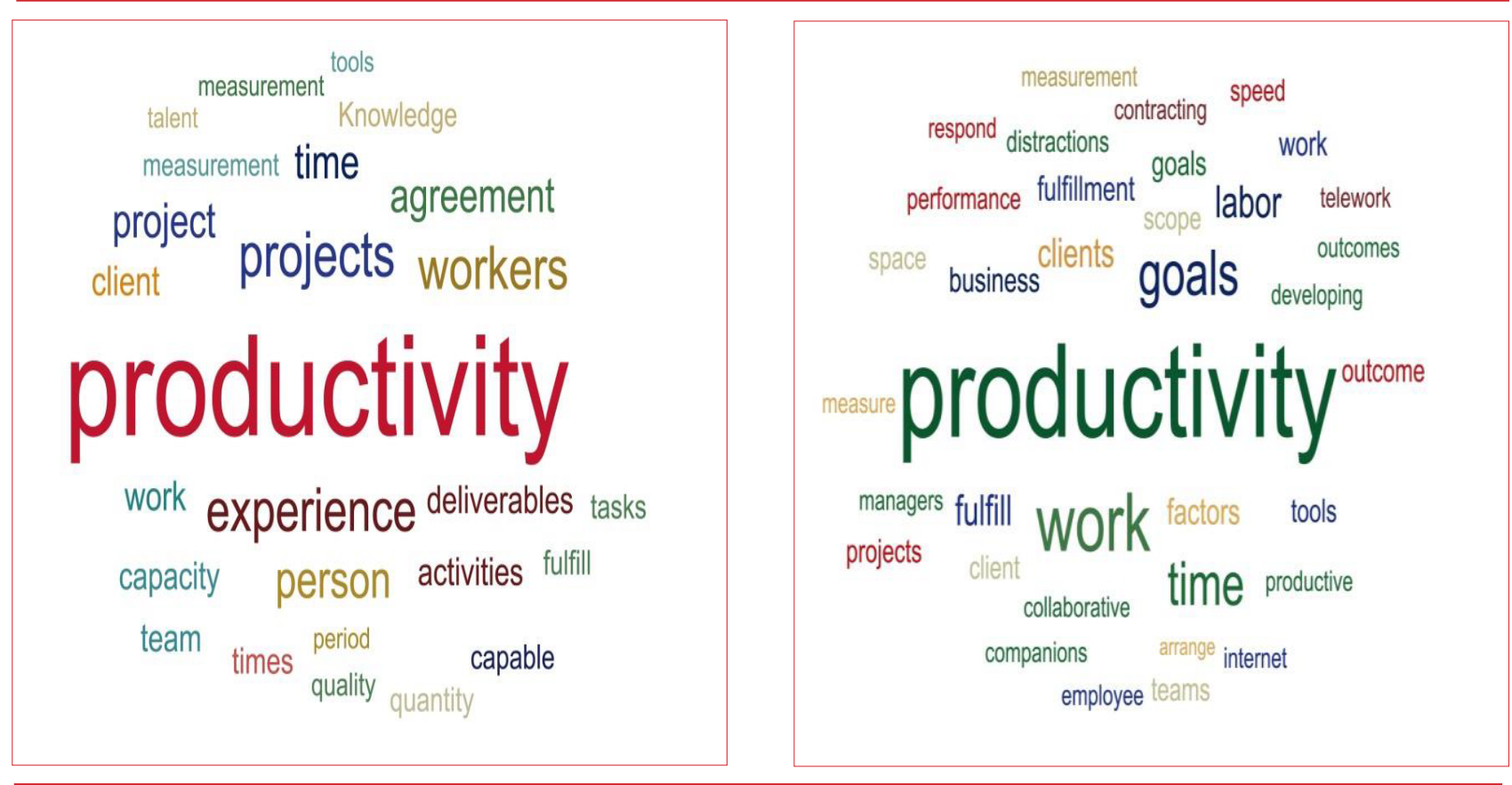

Source: Authors' own elaboration using ATLAS.ti v.8

map generated in VosViewer and obtained from the Web of Science databases, regarding the inquiries undertaken on productivity in knowledge work.

Two closely related concepts, performance and productivity, are the key references. With regards to the above, Tangen (2005) argues that such terms are often confused and considered interchangeable with other terms such as effectiveness, efficiency and cost-effectiveness, and makes the point that performance is a broader concept that includes almost any competition objective and excellence related to costs, flexibility, speed, reliability or quality, and is considered as an umbrella term for all concepts that follow the success of a company and its activities. Other terms that appear related to productivity on the map are satisfaction, organizations, and impact, design and work and knowledge workers, among others.

\subsection{On the concept of productivity in the context of knowledge workers}

There is great diversity in responses regarding the concept of productivity. It shows that some interviewees are more inclined towards objective concepts: "I understand productivity as the ability and speed people have to carry out a certain task assigned to them in the agreed times" (Executive 1). While others turn to terms that are more subjective:

A worker is productive to the extent that he feels comfortable in the workplace and feels he is in a pleasant place, and feels that his experience and training is useful for the work team, and also feels that the tools or infrastructure he is using in that work team is going on efficiently (Executive 13).

The transcripts recorded in ATLAS ti, yielded a word cloud, with both the answers obtained from managers and those provided by workers, as shown in Figure 2. There is some degree of similarity between managers and workers as the results prove, which Davenport (2008) could explain when he stated that today's managers look suspiciously like knowledge workers, given that the way they work resembles the way their employees do it.

It is observed among the differences detected that managers make greater use of terms such as experience, workers, projects, deliverables and agreement. While workers 
Figure 3. ACM perceptual map with referenced categories according to company type

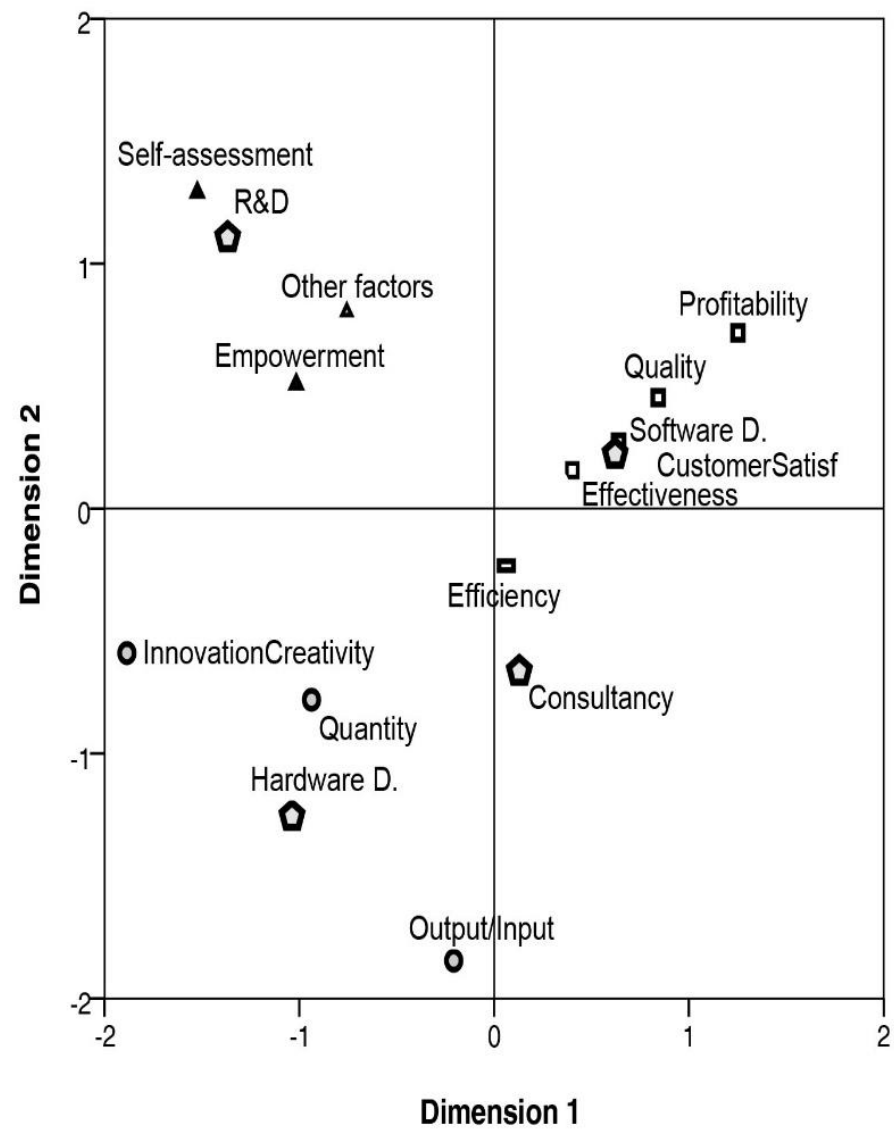

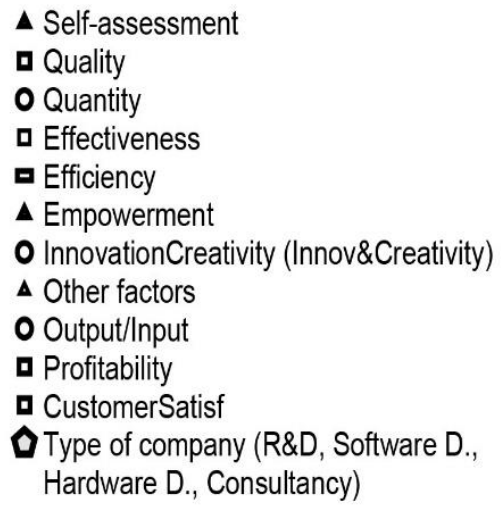

$\Delta$ Self-assessment

口 Quality

O Quantity

口 Effectiveness

- Efficiency

$\Delta$ Empowerment

O InnovationCreativity (Innov\&Creativity)

$\Delta$ Other factors

O Output/Input

- Profitability

- CustomerSatisf

- Type of company (R\&D, Software D., Hardware D., Consultancy)

emphasize in terms such as work, goals, time and fulfillment. Regarding the importance managers attach to experience, Rannacher, Stranzenbach, Sturm, Mütze-niewöhner, and Schlick, (2013) define it as a type of personal knowledge that is difficult to transfer to others, while Davenport (2008) refers to it as an indicator of the worker's ability to cope with complexity.

Considering the variability demonstrated, and in order to delve into the possible differences between companies, the analysis was carried out by grouping them according to the type of core activity performed, as follows: software developers, hardware developers, consulting and research developers and development. Given the qualitative and multivariate nature of the data, and with a view to detect possible association patterns between the coded categories and the type of company, the perceptual map was obtained by applying the Multiple Correspondence Analysis (MCA) (Diaz, 2002), as shown in Figure 3. This reflects that software developers use more intensively traditional terms such as efficiency, effectiveness and profitability, as well as terms related to a customer-oriented approach such as customer satisfaction and perceived quality.

On the contrary, innovation and development companies lean more towards subjective human resource managementoriented concepts such as empowerment, self-assessment, job satisfaction and knowledge management, the latter included in the category of "other factors". On the other hand, the statements of interviewees in hardware developers lean more towards tangible concepts such as quantity and traditional measuring, but also to intangible concepts such as innovation and creativity. 
Figure 4. Semantic network that emerges from the conceptualization of productivity from the perspective of interviewees

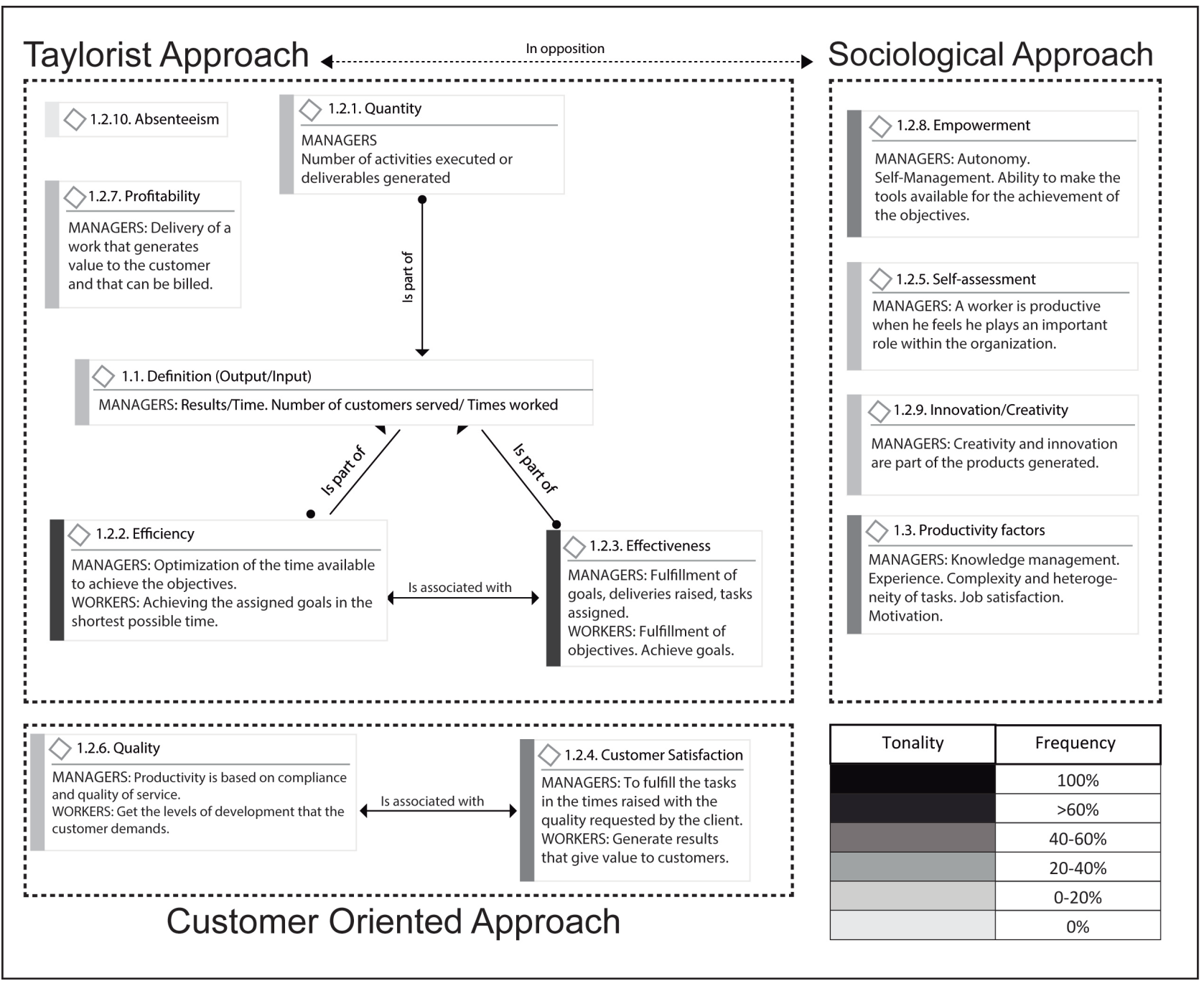

Source: Authors' own elaboration using ATLAS.ti v.8.

Finally, consulting companies do not show a marked behavior, and only show affinity with a traditional concept: efficiency.

Based on the transcripts with a view to systematize the results, we chose to develop a semantic network containing the different perspectives that the interviewees assume when addressing the concept of productivity, which Figure 4 schematizes. The frequency with which they are used also attests to the diversity in concepts, a fact that is outlined in the graph by using different shades in the bars adjacent to the code, presenting the most mentioned categories with a darker shade of gray, and in a lighter shade those that are less emphasized.

The results are consistent with Erne's (2011) proposal, who raises the emergence of two antagonistic approaches. The first approach is called the Scientific or Taylorist Approach, which aims to standardize the work process, turning to the breakdown of tasks into their constituent elements in search of achieving the best work practices. The second approach is called the Human Relations Approach or Sociological Approach and is characterized by a combination of features such as autonomy, teamwork, access 
to information and communication systems, office architecture, among others, whose prospect for success focuses on leveraging the intellectual capital of all employees.

Two classic indicators, efficiency and effectiveness, emerge as the predominant concepts. Which in light of Antikainen and Lönnqvist (2006) could be counterproductive, since the use of traditional terms in productivity measuring often prove inappropriate for measuring knowledge work. However, most researchers usually take them into account because they integrate a more general concept, to wit, performance (Dahooie, Arsalan and Shojai, 2018). It is worth noting the high simultaneity levels in the in the references to efficiency and effectiveness, given its high co-occurrence coefficient of 0.63 . This is understandable considering that only the appropriate combination of both concepts leads to high productivity values (Rutkauskas and Paulavicien, 2005).

On the contrary, there were few references to the elements of quantity and profitability and none to absenteeism at work. As for profitability, some scholars regard the intellectual capital approach focused on financial returns as a plausible alternative to measure knowledge work, based on intangibility and the inability to standardize other types of results (Arsalan et al., 2014). Critics have noted, however, that process analysis and non-financial results remain necessary. Moussa, Bright, and Varua (2017), for example, are opposed to following only profitability indicators for work management supported by the fact that a number of factors outside worker productivity can affect an organization's financial benefits.

On the other hand, and from the opposite perspective, that of human relations, different aspects emerge worth pointing out. This is how many of the managers express their concern and reluctance to follow their employees closely, by neglecting the human part:

I do not like the concept of software factory, used in large companies, which look like factories and workers as operators. They feel bad thinking they're like machines producing. One should think more about the human part, grant them leave for personal errands if they are up to date in their work; that yields better results in productivity than monitoring them closely as if they were working machines (Executive 11).

Among the aspects referred by the interviewees is empowerment: "in this type of sector, productivity is a matter of trust, we take care of our staff, people must be empowered, as well as loyal and committed" (Executive 14). Likewise, there are references to the ability an employee must have to selfmanage: "The possibility for the employee to define his own work structure [...]. In this way, I have learned that people find their own balance point in terms of what to do first, how to do it, what the priorities are" (Executive 9).

In relation to the above, Adriaenssen et al. (2016) point out that the biggest change for knowledge workers is that they must learn to manage themselves, recognize their own strengths and weaknesses, and know where they can make a difference. In this regard, Davenport (2008) promotes the idea that workers should be included in the effort to decide how to measure their productivity, which is justified by the fact that they are knowledgeable in the tasks they carry out, their importance, and the potential metrics that could help assess their performance. Moreover, he proposes to consider the views of a wide range of people in an effort to eliminate possible sources of bias. Nevertheless, researchers such as Dahooei et al. (2018) claim that, in practice, much of the measurement strategies are designed based on suggestions by managers, and consequently the assessment of productivity is carried out by them alone as well.

Regarding the aspects of innovation and creativity, Davenport (2008) suggests that productivity management should not only aim to stimulate the production of knowledge work, but also allow the reflection and creative thinking required by workers in search of greater effectiveness. The testimonies of the interviewees also suggest this kind of reflection: "[...], so many improvements to the process, so many recommendations, so many innovation launched, so many manuals issued, so many courses taught, impact on the region, everything that can help in some way to manage knowledge" (Executive 5). 
In addition, factors such as knowledge management, constant training, work experience, nature of tasks, job satisfaction, among others are mentioned. From the findings obtained by Rannacher et al. (2013), it appears that the core issues in employee satisfaction are the working environment, equipment, health protection, working atmosphere, wages, job security and development potential. Regarding knowledge management, i.e., creation, transfer, capture and distribution of knowledge, Rannacher et al. (2013) claim that it is one of the main input variables in productivity, given that it provides each employee with an increased level of qualification, of course, at the expense of reduced service capacity, and they call for implementing knowledge transfer practices within organizations, conducive to the knowledge of each employee becoming available to all employees in the company. An example of such strategies arises from one of the statements given by one interviewee:

We use other tools such as a YouTube channel where we record training sessions. A person in the functional area who knows accounts payable, purchases, fixed assets, or we at the technician's level of report management, of some tool, we make the recording of a session, upload and share it so that everyone knows that this tool exists and how it is used (Worker 1).

Furthermore, another approach arises and it is applicable to service companies in general, namely, the customer-oriented approach, which includes different aspects in which customers contribute to productivity, such as the impact of customer interaction on process variability, or their role as coproducers, or the conception of quality from the customer's perspective. In this sense, Grönroos and Ojasalo (2004) refer to the fact that service quality and productivity cannot be managed separately. In turn, the aforementioned dilemma also reflects when, on the one hand, there are those who support adopting a humanistic approach that pays more attention to customers, staff, leadership and culture; meanwhile, on the other hand, there are those in favor of implementing a technical quality approach related to operation management, statistics and measuring methods (Anitsal and Schumann, 2007).

\subsection{Challenges in Knowledge Worker Productivity Management}

Among the main challenges and concerns that emerge in practice within organizations in the KIS sector, the following stand out in order of consensus among the interviewees: difficulty in managing task execution times, work heterogeneity, task complexity, processes and results intangibility and, consequently, difficulties in measuring and monitoring, and how to manage measurement practices without affecting the well-being of employees. The findings are described in more detail below.

3.2.1. Time management. One aspect highly agreed upon was time management. The following statement by one of the interviewees allows us to project what has been expressed:

\begin{abstract}
The concurrency of tasks, the pressure to meet deadlines with customers, sometimes leads you to be messy as concerns measurement, feedback and control. You are very focused on the goal and you have to achieve it anyhow [...], then sometimes you cover up things and if you reach the goal because you don't care how, but you did it (Executive 14)
\end{abstract}

There is a general emphasis on the need to record and follow up the time estimated to complete work activities, given that this not only affects the assessment of productivity, but also touches highly sensitive issues such as interaction with clients, with whom the costs of their orders and the time to achieve the results must be agreed. In this regard, Erne (2011) explains that the term time management includes a couple of different but strongly linked challenges: the workload in general and the administrative burden in particular, covering aspects such as performing several tasks in parallel, interaction with different stakeholders, and the amount and accuracy in handling information, and task changing. In relation to this last aspect, an interviewee commented:

When the worker changes contexts, productivity changes by multitasking. I think that is one of the things that brings about a lot of losses and that we fail to observe, I would think that that is something that needs to be analyzed. When you 
change contexts, you take more or less 20 minutes to focus again [...], that is, a person dedicated to the same task over and over again gains speed, but if you remove him from that context and put him to another task, then he loses the speed he had gained (Executive 3).

The theory supports this finding because cognitive psychology considers multitasking and task changing as a source of productivity loss ranging from 20\%to 40\% (Spira and Feintuch, 2005). Along with the above, a challenging problem knowledge workers face in the current information environment is that related to the management of distracting factors. As Ruostela and Lönnqvist (2013) commented, the worker may suffer distractions and information overload caused by multiple emails, social networks, phone calls and instant messages. However, they also argue that the continued development of ICTs not only generates problems, but also many opportunities for more efficient and effective tasks.

\subsubsection{Heterogeneity of the work} carried out. Several executives referred to the diversity of the work done, and mentioned that people have different ways of working and being productive. This heterogeneity is reflected not only among the different organizations but also within them, since the work that employees in the same organization do is very dissimilar and with different complexity. In this sense, Davenport (2008) mentions that although a system programmer and a doctor are both knowledge workers, they have very different educational backgrounds, working conditions, business processes and success measures.

In fact, the knowledge workers' work days are often fragmented and contain several different tasks, such as attending different types of meetings, moving around to meet customers and partners, reading and answering emails, among others, which is associated with idle time (Ruostela and Lönnqvist, 2013). In this regard, Adriaenssen et al. (2016) note that when the main task is evident, one can harness the "lean thinking" method, which involves removing activities with no added value. That way, the activities and processes not specifically related to the main task should, as far as possible, be reduced and preferably eliminated or transferred to others, thereby preventing specialists in a given field of knowledge from using substantial resources to develop activities that do not require their professional skills.

Additionally, the output of products is diverse since the majority are not standardized products, but address particular requirements of the customers, wherefore much of the heterogeneity in the work is brought about by the customers themselves, as the interviewees perceive it and let see in their statements: "the collaborator may tell you that it takes longer because there were too many corrections, because the client changed his mind, started asking us for a printed piece and we ended up making a video" (Executive 3).

3.2.3. Task Complexity. The need for tailored information, use of working time for different activities, projects and specific clients, and therefore specific objectives, and the competencies of employees individually are some examples of the complex nature of knowledge work (Jääskeläinen, Laihonen, and Lönnqvist, 2014). Productivity management should be kept these aspects in mind according to the considerations of the workers themselves: "There are tasks that have a very different level of difficulty and we are evaluated by whether it was done or not, regardless of its level of difficulty, the complexity of the task is something they should take into account" (Worker 3).

3.2.4. Intangibles of processes and products. In knowledge work, both inputs and outputs are usually difficult to define, and one of the reasons is that both are intangible in nature (Ruostela and Lönnqvist, 2013). Some authors have hinted that service organizations have entered a desperate search for results, alluding to the fact that there is a clear need to determine their production unit within companies such as banks, hospitals or consulting agencies (Djellal and Gallouj, 2013). Accordingly, some interviewees illustrate this circumstance in their statements: "there are tangible aspects such as the time people take, the number of defects they have, but there are others that are intangible and are also part of productivity, but we do not know how to measure them" (Executive 1). 
Among intangible things falls, for instance, the degree of recognition of otherinstitutions, which the indicators contemplate but is a little difficult to measure [...], how they see us, how accepted the center is, how much we interact with research groups, with universities, with the government or the private sector (Executive 13).

Likewise, it is difficult to outline the relationship between inputs and outputs given the presence of different variables involved, which makes it confusing to recognize what inputs produced what products (Ruostela and Lönnqvist, 2013). Another intangible aspect to be considered derives from the monitoring of customer satisfaction, which is purely perceptive despite containing some objective elements. Given these circumstances, Laihonen, Jääskeläinen, Lönnqvist, and Ruostela (2012) propose to use subjective measurements, such as conducting interviews and surveys in order to address such challenges, thereby capturing comprehensively the factors that affect productivity, which they also consider a pragmatic way to follow up on a complex and intangible phenomenon.

3.2.5. Difficulty to measure and monitor. There is also high consensus of opinions about the difficulty involved in measuring productivity: "Sometimes it is difficult [to measure] because all people have different ways to work and being productive, so evaluating or standardizing is complicated" (Executive 2).

\begin{abstract}
Basically, measuring productivity in processes like this is complex because to what extent I, as a scientific and technological development center, am productive, that is to say, what makes me productive? Generating products, money, recognition, visibility, good interaction with customers or companies or a mixture of all of the above (Executive 13).
\end{abstract}

Given the aforementioned difficulties, there are those who choose not to make formal measurements. Organizations that have workers skilled in a field emphasize the above, because their bosses being concerned with not interfering in the work characterizes them. As stated by Davenport (2008), when it comes to knowledge workers, smart people are hired and left alone, without quality measurements, no reengineering, and no improvement strategies. In the same vein, Erne (2011) states that managers have the power to intervene in budgetary matters, but less ability to influence very-technical aspects where the worker is expert.

But failure to formally examine the workflow leads to no benchmarks and no accountability for the cost and time consumed by these activities. As a result, it is not possible to determine whether the work done could have been done better (Davenport, 2008). That is why a management system that includes quantitative measuring methods is necessary, not as an evaluation and monitoring strategy only, but as a kind of early warning system at the case or project levels (Erne, 2011). A need that the statements of the interviewees also reflected: "[...] predictive and prescriptive analyses are needed, so that you are able to assemble mathematical and statistical models that can tell us the organization is going this or that way" (Executive 5).

3.2.6. Workers' welfare. Another challenge usually mentioned by the interviewees concerns the explicit interest in achieving workers' welfare, a challenge several reasons bring about including the fact that the service sector is more staff-intensive than manufacturing (Rutkauskas and Paulavicien , 2005), as well as Peter Drucker's (1999) call to consider knowledge workers as assets. Accordingly, some managers express a noticeable need to retain a valuable asset such as qualified and experienced staff:

Knowledge is complicated and people who have knowledge have control and then you have to make them feel important so that knowledge stays with you, because knowledge goes away at any time [...], it is a sector with certain particularities and challenges in terms of retaining people and maintaining that appropriate environment (Executive 14).

Another important factor in keeping the knowledge worker motivated is related to the content of the job, the opportunity to develop skills and grow professionally. In this regard, Antikainen and Lönnqvist (2006) argue that an influencing aspect in job satisfaction arises from the internal motivation to work, because they find it fun, interesting, exciting and demanding. Some statements by workers 
also account for the above: "The type of task influences [productivity], sometimes I have different tasks and those that are very repetitive I feel discourage me and I take a little longer, while those that require more analysis can motivate me" (Worker 3). "Learning new things motivates me, make it not so routine-like in the sense that we get to do the same reviews, but to be in situations that force me to learn" (Worker 1).

\section{Recommendations}

The findings reveal the need for a more general definition of productivity within the context of knowledge work, as well as for the use of alternative productivity management strategies. With regard to the first issue, this research abides by the recommendations that emerge from different research contributions in the field, leading to adopting a holistic definition. Specifically, the proposal made by Dahooei et al. (2018, p. 1771) goes beyond the restrictive traditional definition, enabling better management for work productivity improvement in this sector:

\section{Knowledge worker productivity is a concept that determines to what extent a knowledge worker delivers products or achieves the intended goals of his work in a creative, efficient and effective manner within a specific timeframe, considering his own competencies, knowledge, talents and standard skills required for the job.}

In this regard, Erne (2011) comments that the core of the concept of productivity should emphasize more on the contribution that the employee makes to a particular business, rather than on the achievements of a single person or group of people, a contribution that can consist in acquisition, generation, dissemination, application, retention and/ or evaluation of knowledge. In the same sense, many authors stress the importance of gearing the definition of productivity towards the added-value approach. Verbigracia, Rutkauskas and Paulavicien (2005) assert that sound productivity is achieved when the activity of an organization and the resources used in the transformation process add value to the product.

With regards to management strategies aimed at increasing productivity, Erne (2011) proposes that business management should concentrate on finding ways to reduce multitasking and task changing, focusing on just a few and making it possible to develop skills in the workplace, create balance between regulations and autonomy, and make expert performance assessable. To that end, few clear, business-specific productivity indicators should be established that do not necessarily have to be measured, but can be evaluated according to the indicators defined. He also invites managers to learn more about the nature expert work; otherwise, it will be nearly impossible to influence their work.

Finally, there is a call to involve the various stakeholders such as employees, clients and supervisors in the whole measurement process (Anitsal and Schumann, 2007), despite acknowledging that such an approach has so far been used mainly for academic purposes and not as a professional tool in managerial practices (Antikainen andy Lönnqvist, 2006).

\section{Conclusions}

The testimonies collected attest to an existing gap in between perspectives in which the productivity of workers is conceived and measured. On the one hand, there are those who perceive productivity from an objective measuring or Taylorist approach, prone to process standardization and including quantitative metrics. Within the opposite perspective fall the most prone to subjective or sociological measurements, whose approach contemplates monitoring the human aspects immersed in productive processes, such as worker empowerment, self-management, innovation and creativity contributions, knowledge management and the role of motivation and job satisfaction to successfully achieve goals. Another approach emerges at the same time; it is client-oriented as it contemplates the participation of the client, his perception of quality, perceived added value, and their role as co-producer of productivity.

Interviewees from software developers lean further towards the concepts of efficiency, quantity and customer satisfaction, while those in research and development show greater affinity for humanistic concepts such as empowerment, self-evaluation, work 
satisfaction and knowledge management. On the other hand, the staff in hardware developers identifies better with the classic idea of productivity, while those in consulting companies tie it closely to the concept of efficiency. Among the most highlighted difficulties by the interviewees are those related to time management, the nature of the tasks performed and the managerial concern to manage measurement practices without undermining the well-being of employees.

The analysis shows the need to adopt the concept of productivity from a holistic perspective, which goes beyond traditional concepts such as quantity, efficiency, effectiveness and profitability, and contemplates including elements that account for knowledge capital and human relationships in the labor process. As well as the implementation of management strategies that reckon the different perspectives of different stakeholders such as workers, colleagues and clients, and the managers themselves.

\section{Conflict of interest}

The authors declare no conflict of interest.

\section{Source of Financing}

This research was financed through the project: "Productivity measurement model for teleworkers of companies in the service sector in Manizales" by the Universidad de Caldas (Code 0494917) and the Universidad Nacional de Colombia Sede Manizales (Code Hermes 36757)

\section{Acknowledgement}

We thank the staff of the research units of the Universidad Nacional de Colombia Sede Manizales and the Universidad de Caldas for the institutional support received.

\section{References}

Adriaenssen, D. J., Johannessen, D. A., \& Johannessen, J. A. (2016). Knowledge management and performance: Developing a theoretical approach to knowledge workers' productivity, and practical tools for managers. Problems and Perspectives in Management, 14(3), 667-676. $\quad$ https://doi.org/10.21511/ ppm.14(3-3).2016.10

Anitsal, I., \& Schumann, D. (2007). Toward a Conceptualization of Customer Productivity: The Customer's Perspective on Transforming Customer Labor into Customer Outcomes Using Technology-Based Self-Service Options. The Journal of Marketing Theory and Practice, 15(4), 349-363. $\quad$ https://doi.org/10.2753/ MTP1069-6679150405

Antikainen, R., \& Lönnqvist, A. (2006). Knowledge work productivity assessment. Institute of Industrial Management. Tampere, Finland: Tampere University Tecnhology. Retrieved from https://www.researchgate.net/ publication/228397441 Knowledge work productivity assessment

Arsalan, M.R, Dahooei, J.H, \& Shojai, A.Z. (2014). A value-based framework for the assessment of knowledge workers. VINE, 44(2), 295-318. https://doi.org/10.1108/VINE-05-2012-0017

Dahooie, J.H., Arsalan, M.R., \& Shojai, A.Z. (2018). A valid and applicable measurement method for knowledge worker productivity. International Journal of Productivity and Performance Management, 67(9), 1764-1791. https://doi. org/10.1108/IJPPM-07-2017-0176

Davenport, T. H. (2008). Improving Knowledge Worker Performance. From Strategy to Execution, 215-235. https://doi. org/10.1007/978-3-540-71880-2 11

Díaz L. G. (2002). Estadística Multivariada: inferencia y métodos. Bogotá, Colombia: Facultad de Ciencias, Universidad Nacional de Colombia.

Djellal, F., \& Gallouj, F. (2013). The productivity challenge in services: Measurement and strategic perspectives. Service Industries Journal, 33(3-4), 282-299. https://doi.org/10.108 $\underline{0 / 02642069.2013 .747519}$

Drucker, P. (1999). Knowledge-Worker Productivity: The Biggest Challenge. California Management Review, 41(2), 79-94. https://doi. org/10.2307/41165987

Erne, R. (2011). What is Productivity in Knowledge Work? Journal of Universal Computer Science, 17(10), 1367-1389. Retrieved from https://pdfs. semanticscholar.org/f1ab/78a5d7aa68a7ade04 2735f5db7d8d3fab94d.pdf 
Flick, U. (Ed.). (2014). The SAGE Handbook of Qualitative Data Analysis. Washington, D.C., USA: SAGE Publications.

Grönroos, C., \& Ojasalo, K. (2004). Service productivity - Towards a conceptualization of the transformation of inputs into economic results in services. Journal of Business Research, 57(4), 414-423. doi https://doi.org/10.1016/ S0148-2963(02)00275-8

Jääskeläinen, A., Laihonen, H., \& Lönnqvist, A. (2014). Distinctive features of service performance measurement. International Journal of Operations and Production Management, 34(12), 1466-1486. https://doi. org/10.1108/IJOPM-02-2013-0067

Laihonen, H., Jääskeläinen, A., Lönnqvist, A., \& Ruostela, J. (2012). Measuring the productivity impacts of new ways of working. Journal of Facilities Management, 10(2), 102-113. https:// doi.org/10.1108/14725961211218749

López, A., y Ramos, D. (2013). ¿Pueden los servicios intensivos en conocimiento ser un nuevo motor de crecimiento en América Latina? Revista Iberoamericana de Ciencia, Tecnología y Sociedad -CTS, 24(8), 83-115. Recuperado de https://www.redalyc.org/ articulo.oa?id $=92429917006$

Moussa, M., Bright, M., \& Varua, M. (2017). Investigating Knowledge Workers' Productivity Using Work Design Theory. International Journal of Productivity and Performance Management, 66(6). https://doi.org/10.1108/ IJPPM-08-2016-0161

Patton, M. Q. (2002). Qualitative Research and Evaluation Methods (3a ed.). London, England: Sage Publications.

Ramirez, Y. W., \& Nembhard, D. A. (2004). Measuring knowledge worker productivity.
Journal of Intellectual Capital, 5(4), 602-628. https://doi.org/10.1108/14691930410567040

Ramirez, Y. W., \& Steudel, H. J. (2008). Measuring knowledge work: the knowledge work quantification framework. Journal of Intellectual Capital, 9(4), 564-584. https://doi. org/10.1108/14691930810913168

Rannacher, A., Stranzenbach, R., Sturm, F., Mütze-niewöhner, S., y Schlick, C. (2013). A System Dynamics Model for the Evaluation of the Productivity of Knowledge-intensive Services. IBusiness, 5(3B), 55-58. http://dx.doi. org/10.4236/ib.2013.53B012

Ruostela, J., \& Lönnqvist, A. (2013). Exploring More Productive Ways of Working. International Journal of Social, Behavioral, Educational, Economic, Business and Industrial Engineering, 7(1), 153-161. Retrieved from https://pdfs.semanticscholar.org/8d69/ dcb496ec90842fae80c401db5efbe3439d8e.pdf

Rutkauskas, J., \& Paulavicien, E. (2005). Concept of Productivity in Service Sector. Engineering Economics, 43(3), 29-34. Retrieved from https://pdfs.semanticscholar.org/b3bf/ $\underline{\text { be4e1f320398977b9fb6e9c1d903f8e9c551.pdf }}$

Schreier, M. (2012). Qualitative Content Analysis in Practice. London, England: Sage Publications.

Spira, J., \& Feintuch, J. (2005). The cost of not paying attention: how interruption impacts knowledge worker productivity. New York, USA: Basex, Inc. Retrieved from https:// iorgforum.org/wp-content/uploads/2011/06/ CostOfNotPayingAttention.BasexReport1.pdf

Tangen, S. (2005). Demystifying productivity and performance. International Journal of Productivity and Performance Management, 54(1), 34-46. https://doi. org/10.1108/17410400510571437

\section{¿How to quote this article?}

Tapasco-Alzate, O. A., Giraldo-García, J. A., \& Osorio-García, D. (2020). Work productivity management in knowledge-intensive service companies: considerations and challenges. Cuadernos de Administración, 36(6), 64-77. https://doi.org/10.25100/cdea.v36i66.8465

Cuadernos de Administración journal by Universidad del Valle is under licence Creative Commons ReconocimientoNoComercial-SinObrasDerivadas 4.0. Based in http://cuadernosdeadministracion.univalle.edu.co/ 